\title{
BALKANLAŞTIRMADAN AVRUPALILIĞA: HIRVATİSTAN SİNEMASINDA YENİ ÖZNELLİK BİÇIMLERINIIN ÇÖZÜMLENMESİ
}

Özge Baydaş Sayllgan

Sakarya Üniversitesi Sanat Tasarım ve Mimarlık Fakültesi

Balkanlaştırma, sinemadaki temsiliyle, sınırları belirsiz bir coğrafyaya dair tahayyülün Batı merkezli bakış açısından ideolojik bir yeniden üretim alanı oldu. Bu bağlamda oryantalizmle de ilişkilendirilerek onun bir türevi olarak da okundu. Fakat Balkanlaştırma bakış açısı, öz-Balkanlaştırma ve öz-egzotikleştirme pratikleriyle içeriden de desteklenen ve üretilen bir temsil biçimi doğurdu. Bu belirsiz bölgenin bileşenlerinden biri olarak Hırvatistan'ın sineması, oldukça hızlı dönüşümlere sahne olan toplumsal ve politik bir arkaplanda, ulus devletleşme ve Avrupalılaşma sürecinde, savaş sonrası travmalarıyla yüzleşirken, yeni ulusal özneleri tanımlamaya / inşa etmeye başladı. Bu yüzleşmenin önemli bir bölümü yakın geçmişin öteki'leri üzerinden kendini tanımlama halinde gerçekleşirken, bir bölümü de yeni sistemle ve süregelen kapitalist-ataerkil toplumsal yapıyla oldu. Bu araştırma kapsamında 2000-2015 arası Hırvatistan sinemasında karşımıza çıkan yeni öznellik biçimleri öz/Balkanlaştırma, kendini yok eden özne, alt-üst ötekilik, gelenek ve modern arasında bir başka öteki olarak kadın özneler, geç-modernitede projeye dönüşen özne vb. kavramsallaştırmalar içinde incelenmiştir.

Anahtar Sözcükler: Balkanlaştırma, sinema, Hırvatistan, öznellik, Öteki, travma.

Bu çalışma 17 Nisan 2017 tarihinde sinecine dergisine ulaşmış, 5 Ağustos 2017 tarihinde kabul almıştır.

ozgesayilgan@gmail.com 


\title{
From Balkanization to Europeanization: An Analysis of Subjectivity in Croatian Cinema
}

\begin{abstract}
Balkanization and its cinematographic representation became an ideological reproduction space from the western perspective of imagining a geography with indeterminate borders. In this context, it is seen as a derivative of Orientalism. But this perspective of Balkanization generated a representation that was supported and reproduced from inside through self-Balkanization and self-exoticism. Croatian cinema, in the context of this undefined region, constructed new national subjects while facing post-war trauma in a process of nationalization and Europeanization, while the sociological and political background became the scene of rapid and succesive transformations. A significant part of this confrontation consists of self-determination over the other of recent past and the rest is of a new system and a continual capitalist-patriarchal social structure. In this article, the new subjectivity forms in Croatian cinema between 2000-2015 are analyzed in terms of concepts such as self-Balkanization, self-destructive subject, upper and lower others, woman subjects as another other between tradition and modern, and subject transformed into project in late-modernity.
\end{abstract}

Keywords: Balkanization, cinema, Croatia, subjectivity, Other, trauma. 


\section{Giriş $^{1}$}

Tarih boyunca Balkanlar olarak adlandırılan coğrafi bölgenin sınırlarının nerede başlayıp bittiği ve Balkan tanımının neyi ifade ettiği sorularına verilen yanıtlar değişkenlik gösterir. Balkanlar da tıpkı "Ortadoğu" gibi var olan tanımlı fiziksel coğrafi bir bölgenin adı değil, sınırları ve içeriği sürekli belirsiz, tartışmalı ve değişken, "Batı"nın inşa ettiği daha çok siyasal ve ideolojik bir anlama sahip imgesel coğrafi bir alanı işaret eder. Edward W. Said'e göre (2014) nasıl Batı'nın kendisi belli bir yer değilse, Doğu da belli bir yer değildir. Balkanlar ise sınırları belli olmayan bu iki alan arasında siyasal, toplumsal, ekonomik, kültürel ve elbette coğrafi bir tampon olarak işlev görmüştür ve görmeye devam etmektedir. Fikirler, kültürler ve tarihlerin gerçekten anlaşlabilmesi için bunların iktidar yapılarının ve egemenlik ilişkilerinin incelenmesi gereklidir. Buradan yola çıkarak Said, Doğu ve Batı arasındaki ilişkiyi bir iktidar ve derecesi değişen bir egemenlik ilişkisi olarak çözümlemeyi önerir (Said, 2014, s. 15).

Balkan sineması üzerine çalışan Dina Iordanova da Balkan coğrafyasını tanımlama çabasıyla işe koyulur. Iordanova'nın Balkanlar yaklaşımı eski Yugoslavya ile aynı değildir; Küçük Asya, Doğu Akdeniz Adaları ve Kafkaslar'ın Karadeniz kıyılarına sınırı olan Güneydoğu Avrupa'daki daha geniş bir bölgeyi ifade eder.

"Balkanlar, benim kullanım biçimimde coğrafi bir kavram olmayıp, büyük ölçüde Bizans, Osmanlı ve Avusturya-Macaristan ortak mirasıyla ve bölgenin Avrupa kıtasının batı tarafı karşısındaki özel sınırsal konumuyla tanımlanan kültürel bir unsura işaret eder" (Iordanova, 2007, s. 3). Iordanova'ya göre Bulgaristan, Makedonya, Sirbistan, Karadağ, Bosna-Hersek, Arnavutluk, Hirvatistan, Slovenya, Yunanistan, Romanya, Moldova ve Türkiye tarihleri, mirasları ve öz-kavramsallaştırmalarındaki birçok unsur açısından Balkan'dırlar (Iordanova, 2007, s. 3). Buna karşın "Balkanlllık"ın her ulus için kendisinin Doğu'sundaki öteki'ye atfedildiğini ileri süren Slavoj Žižek'e göre; kim Avrupa'nın bu doğu yakasının batısına yerleşmiş bulunursa kendilerini derhal en batı sınır olarak ortaya koymakta; güneyde ve doğuda kalan her şeyden bar-

1 Bu araştırma Sakarya Üniversitesi Bilimsel Araştırma Projeleri desteği ile Zagreb Üniversitesi Dramatik Sanatlar Akademisi'nde Prof. Dr. Saša Vojković'in danışmanlığında Yrd. Doç. Yüce Sayılgan ile birlikte Temmuz-Ekim 2015 tarihlerinde gerçekleştirilmiştir. 
bar bir çöl olarak söz etmektedir (Žižek'ten aktaran Iordanova, 2007, s. 49). Žižek'e göre Balkanlar, Batılı bakış açısından her zaman uygarlaşmamış veya barbar ötekiyi tanımlar. Žižek, Balkan hayaletini; Balkan bölgesinin Avrupa'nın diğer bölgeleri hızlıca küreselleşme sürecine uyum sağlamışken, hiçbir şeyi unutmayan ve hiçbir şey öğrenmeyen, hala yüzyıllık savaşları sürdüren, geçmişin kötü şöhretli hayaletlerince büyülenmiş bir parçası olduğu klişesini tartışmaya açar. "Balkanlar nerede başlar?" sorusuna verilecek kesin bir yanit ise bulunmaz; Balkanlar her zaman başka bir yerde, biraz daha güneydoğuda bir yerlerdedir (Žižek, 2001, s. 3).

Balkanlaştırma, Maria N. Todorova'ya göre yirminci yüzyllın başlarından itibaren, Avrupa için sadece geniş ve canlı politik birimlerin parselizasyonu anlamına gelmiyordu; fakat aynı zamanda kabileye, çağdışı olana, ilkelliğe ve barbarlığa bir geri dönüşle eş anlamlıydı (Todorova, 1997, s. 3). Coğrafi bakımdan Avrupa'dan çıkarılamayan ancak kültürel anlamda da öteki biçiminde inşa edilen Balkanlar, zamanla bir dizi siyaasal, ideolojik ve kültürel dışlanmanın nesnesi haline gelmiş; Avrupa'nın ve Batı'nın olumlu ve kendini olumlayan bir biçimde kurulan imajının karşısında, bir olumsuz karakteristikler haznesi görevi görmüştür (Todorova'dan aktaran Iordanova, 2007, s. 68). Balkanlar eski Doğu Bloğu'nun "kültürel anlamda yetersiz" bir yığını olarak gösterilmiş ve semantik Avrupa alanının dışına bırakılmıştır (Iordanova, 2007, s. 56). Martina Kiseljak'ın 2012 yı lında Recite Al Jazeeri TV programında Žižek ile yapmış olduğu söyleşide, Žižek Balkanların, tüm Avrupalı travmaları, Avrupa'nın kendisine atfetmeye yanaşmadığı her şeyi, tamamen Balkanlar ile sunulan şiddeti, anti-feminizmi, militarizmi ile aslında Avrupa'nın bilinçaltı olarak işlediğini belirtir (Kiseljak, 2012).

Bununla birlikte, onların "Avrupalılıkları özvarlıklarının temelinde bulunan ancak onlardan geri alınmiş ve yeniden talep edilmesi gereken bir öz niteliktir" (Iordanova, 2007, s. 36). Dolayısıyla Balkanlar'a atfedilen olumsuz anlam sadece komünist geçmişinden değil aynı zamanda Osmanlı hâkimiyetiyle ilişkili geçmişinden de kaynaklanır. Orta Doğu Avrupa ülkeleri bakımından Avusturya-Macaristan'ın imparatorluk miraslarının aksine (toplumsal gelişimi hızlandırdığına ve bugünkü Avrupa'nın ayrıcalıklı statüsüne katkıda bulunduğuna inanılan bir mirastır bu), Osmanlı hâkimiyetinin Avrupa'nın bir parçası olarak Balkan ülkelerinin gelişmesini önemli ölçüde kesintiye uğrattığı düşünülür ve bu ülkelerin, Avrupa ideallerine erişmelerinde önemli 
bir engel olarak kavramsallaştırılır (Iordanova, 2007, s. 43). Bu olumsuz Balkan tanımının bir işlevi de, Yugoslav kimliğinden ulusal kimliğe geçiş politikalarının bir parçası olarak okunabilir. Böylece bütünleştirici bir Balkanlaştırma ideolojisine karşı, yeni Avrupalı ulusal kimliklerin inşa süreci, aslında tüm bir geçmişle hesaplaşma biçiminde gerçekleşme yolunda gelişmiş görünmektedir. Örneğin, Hırvatistan ve Slovenya, Yugoslavya'dan ayrıldıktan sonra, "Balkan" adıyla anılmama arzularını belirten resmi belgeler yayınlamışlardır. Ayrıca, 1930'larda Hırvat İşçi Partisi başkanı Stjepan Radić ısrarla şu görüşü savunur: "Bizim görevimiz Balkanlar'ı Avrupalılaştırmaktır, Hırvat ve Slovenleri Balkanlaştırmak değil" (Cohen'den aktaran Iordanova, 2007, s. 40). Her büyük Balkan şehrinde Avrupa ismini taşıyan bir otel ve bir kafe, bazen de bir sinema salonu vardır (Hatta Zagreb'de Balkan sinemasının adı Avrupa sineması olarak değiştirilmiştir) (Iordanova, 2007, s. 39).

Buna karşın Todorova, Balkanlaştırma kavramının doğrudan oryantalizm içinde değerlendirilmesi yerine kendi öz nitelikleri ve tarihselliği içinde kavramsallaştırılması gerektiğinin altını çizer (Todorova, 1997, s. 7). Todorova'ya göre, kavram Said'in oryantalizm yaklaşımını Batı'nın Balkanlarla olan ilişkisini tanımlamada yeterli gören entelektüeller tarafından ileri sürülmüş ve popülerleştirilmiştir. Bu ilişki üzerinden gittikçe büyüyen ve yaygınlaşan ilgi derecesinde, söylemin çerçevesi açıkça belirtilmeden oryantalizm kategorisi içinde çizilmeye başlamıştır. Todorova Balkanlaştırmanın oryantalizmin bir alt türü olmadığını ileri sürerek, kavrama daha yakından bakmak gerektiğini önerir (Todorova, 1997, s. 8). Öncelikle Balkanlar Yakın veya Ortadoğu'dan jeopolitik açıdan ayrıdır. Kolonyal mirasın olmaması da başka önemli bir farklılık olarak durmaktadır. Balkanların yaygın olan Hristiyan karakteri de -Doğu ile özdeşleştirilen ve Batı'dan farklı olarak "oryantal despotizmin bir türevi" Ortodoks kimliğin vurgulanmasına karşın, İslam karşısındaki potansiyel duruşu ile etkin bir fark oluşturmaktadır. Son olarak, oryantal ötekiye karşı dikilmiş olan pek çok Balkan öz-kimliği de Balkanlaştırma kavramını özerk konumuna yerleştirmektedir ve bunun içinde kendi tarihinin bir bölümünün (özellikle de Osmanlı dönemi ve mirasının) "oryantalizasyonu'"'vardır (Todorova, 1997, s. 20).

Saša Vojković'e göre ise Balkanlar anlam olarak bugün değişikliğe uğramıştır. Vojković, demokratik ve uygar Batı Avrupa'da "çokkültürlülük"ün bir mite dönüştüğünü vurgular ve Balkanlar yerine artık Gü- 
neydoğu Avrupa bölgesi tanımlamasını siyasal olarak daha doğru bir kullanım olarak önerir (Vojković, 2008, s. 83). Vojković'e göre, "Avrupalı" olurken, çağdaş Hırvat sineması Balkan öznelliğini yapısöküme uğratır ve yeniden inşa eder. Çokkültürlülük Avrupa için bir mite dönüşürken, bugün Balkanlar yerine Vojković'in önerdiği şekliyle, Güneydoğu Avrupa bölgesi için bir gerçek olarak karşımıza çıkar. Ötekiliğin kabul edilmesi, toplumsal cinsiyet, ulusal ve etnik kimliklerin yeniden düzenlenmesi; ideolojik ve patriyarkal normların sınırlandırılmasının getirdiği alt üst oluş, savaş sonrası dönemin ve geçiş sürecinin getirdiği zorunlu sonuçlardır. (Vojković, 2008, s. 84). Vojković'in çağdaş Hırvat sinemasını tanımlayabilmek için incelediği filmlerin büyük bölümü savaş tarafindan travmatize edilmiş ve bilinmez bir yere varmak zorunda kalan kadın veya erkek özneyi yeniden inşa eder (Vojković, 2008, s. 95). Fakat bu yeniden inşa sürecinde Kendilik sürekli öteki'nin yardımıyla yeniden görünür olmaktadır. Yeni ulusal kimliğin inşası öteki kimliklerle çatışma, karşılaşma, yüzleşme ve yeniden uzlaşma, tarihsel ve bölgesel tüm ilişkilerin yeniden gözden geçirilmesi yoluyla gerçekleşecektir. Elbette yakın tarihin en yıkıcı olaylarından etnik temelli savaş yeni öznelerin en çok yüzleştikleri tarihsel olay olarak etkisini gösterir.

Doksanlı yıllarda, duvarın yıkılması ve Avrupa haritasının ve sınırlarının değişmesi sadece siyasal bir süreç değildi. Bu aynı zamanda içinde sinemayı da kapsayan geniş bir kültürel alanın bulunduğu imgesel bir coğrafyanın yaratılma süreci olarak yaşandı. Hall'a göre; "Engeller yıkılır yıkılmaz, Avrupa kendisi adına yeni birtakım sınırlar inşa etmeye koyuldu" (Hall'dan aktaran Iordanova, 2007, s. 47). Duvarın yıkılması ve Komünist Blok'un dağılmasıyla birlikte, sınırların yeniden hayal edilmesi gerekti. Böylece "Balkanlar açısından yeniden haritalandırma her iki yönde de gerçekleşiyordu; Üçüncü Dünya'yla yeni ilişkileri sık sık dile getirilirken, barbar Osmanlı mirasıyla aralarındaki eski ilişkiler de derhal yeniden gündeme getirildi (...)" (Iordanova, 2007, s. 51).

Balkan temsilinin ana akım sinemada, edebiyat ve haberleşme medyasında çizilen ve tekrarlanan görüntüsü; ilkellik, fakirlik, savaş, çılgınlık ve barbarlık gibi özellikleri vurgulayarak "uygar" ve "rasyonel" olanın karşısında yer alan bir Balkan imajını inşa etmiştir. Todorova, özellikle Balkan anlatısına odaklanarak, Balkanizmin ve onun öznesi olarak "Balkanlar"ın "Batı medeniyeti"nin karanlık ötekisi olduğu bir söylem alanına hapsedildiğini belirtse de (Todorova'dan aktaran Iorda- 
nova, 2007, s. 68), Balkanlaştırma söylemi sadece dişardaki / merkezdeki Batı tarafından üretilen bir söylem değildir. "Balkanlar'ın 'Oryantalizasyonu'nun tamamen Batılı bir proje olduğu söylenemez, çünkü bu, aynı zamanda gönüllü Balkan entelektüelince kucaklanmış, içselleştirilmiş ve kısmen sürdürülmüş bir süreçtir" (Iordanova, 2007، s. 69).

\section{Seyahat Anlatısı ve Öz-Balkanlaştırma}

Balkanlaştırmanın ötekinin ideolojik inşası olarak gerçekleşmesinde Balkan sineması ve Balkanlar üzerine çekilmiş olan Batı sinemasının da bu imgesel alanın tasvirinde önemli bir rolü olmuştur. Öncelikle seyahatname anlatısı Balkan anlatısının önemli bir bölümünü oluşturur. Balkan coğrafyası, bir seyahatte içinden geçilen, bu sınırları belirsiz coğrafyada, tarihin farklı katmanlarından birinde veya birkaçında türlü çılgınlıklarla, savaş ve akıl almaz olaylar ve kişilikler ile karşılaşılan, eninde sonunda biten, gezgin Batılı öznenin güvenli evine döndüğü bir seyahat kurgusu içinde defalarca yeniden anlatılmıştır.

Iordanova da özellikle Before the Rain (Yağmurdan Önce, Milcho Manchevski, 1994), Underground (Yeralt1, Emir Kusturica, 1995), To vlemma tou Odyssea (Ulis'in Bakışı, Theodoros Angelopoulos, 1995) gibi Balkan anlatısının uluslararası alanda en çok bilinen ve Balkan coğrafyasının yaygın imgelerini inşa etmiş olan örnekler üzerinden karanlık, kasvetli ve yoksul Balkanlar'a; yani savaşlar ve felaketlerin şimdiki zamanda veya geçmişte yaşanmış olduğu bu daha doğudaki coğrafyaya yolculuk eden Batılı öznenin gözünden anlatılan ve çoğu zaman bir gezi, yolculuk veya ziyaret olarak gerçekleşen seyahatname kalıbını inceler (Iordanova, 2007, s. 67-88) . Bu kalıp içinde "tipik olarak Batılı bir kahraman Balkanlar'a gider ve ötekiyle, farklı deneyimlerle karşılaşır ve bu deneyimleri hep, asıl olan Batılı çıkış noktasına referanslarda bulunmak suretiyle, dinamik bir biçimde değerlendirerek yaşar" (Iordanova, 2007, s. 72). Seyahatname anlatı yapısının dişında güncel sıkıntıların gündeme getirildiği Balkan sineması da bir bölümüyle Batı'nın perspektifini eleştirmek ve hatta dönüştürmek yerine, bu perspektife sahip çıkarak kendi içinde bu "gelenekselleşmiş" anlatı biçimini içselleştirme yoluna gitmiştir. Ayrıca bu eleştirel yaklaşım eksikliği, Balkanlar'ın coğrafi ve bazı ülkeler için siyasi açıdan Avrupa'ya dâhil olsa bile kavramsal açıdan Avrupa kültür alanından dışlanarak marjinalleştirilmesi ve ötekileştirilmesi için zemin hazırlamıştır (Iordanova, 2007, s. 69). Öz-balkanlaştırmanin (self-balkanization) bu biçimi kendi tarihine, kültürüne ve kimliğine dışarıdan -daha Batı'dan- bakma ve kendi ken- 
dini egzotikleştirme yoluyla tasvir etme halinde somutlaşır.

Yugoslavya sonrası Balkan sinemaları ulus devletleşme ve ardından Avrupalılaşma süreci içinde Balkanlaştırma ve öz-egzotikleştirme dilinden uzaklaşarak, komünizmden kapitalizme geçiş sürecinde asılı kalmış gündelik yaşam öykülerine daha gerçekçi bir açıdan odaklanılan bir döneme girer. Savaş sonrası travmaların anlatıldığı öykülerin yoğunluğu devam etse de, bu yeni dönemin filmleri "Balkan şiddetinin grotesk, gerçeküstü ve potansiyel olarak öz-egzotikleştirici tanımlarından neo-kapitalist toplumların ekonomik gerçekliklerinin yansıtıldığı kasvetli bir realizme eğilimi yansıtan, Jurica Pavičić'in (2011) deyişiyle 'egzotik olmayan kent arka planında geçen yalın, minimalistik dramalara' doğru kaymaya başlamıştır" (Kovačević, 2013, s. 190). Bu çalışma kapsamında incelenen Hırvatistan sineması örnekleri, eski Yugoslavya'nın bu parçasının uluslaşma ve Avrupa'ya kabul edilme sürecinin yaşandığı böylesi bir dönem içinde çekilmiş olan (2002-2015) filmler arasından seçilmiştir. Bu süreçte Hırvatistan Avrupalılaşma üzerinden ulus devletleşirken ve toplumsal düzlemde yeni Hırvat kimliğini kurarken, sinema perdesinde kurgulanan / inşa edilen; eleştirilen veya özdeşleşilen yeni Hırvat öznesinin görünümü araştırmanın temel sorunsalını oluşturmaktadır. Geçmişle, özellikle de yakın tarihle olan hesaplaşma, savaş sonrası yaşanan travmalar, Balkanlaştırma politikalarına yeni bakış açıları, kimlik, öteki'ye bakış ve yeni öznelerin toplumsal alanla ilişkileri vb. konular bu temel sorunsalın etrafinda gelişen önemli soru başlıkları olarak durmuştur. Fredric Jameson'ın politik bilinçdışı yaklaşımdan yola çıkılarak, sinemanın da içinde bulunduğu anlatı alanının toplumsal ve politik alanlara ilişkin verileri okumada yararlı olacağı düşüncesinden hareket edilmiştir. Jameson'a göre, metinler önümüze daima okunmuş olarak gelmektedir ve onları önceki yorumların tortulaşmış tabakaları ya da eğer metin yeniyse, miras kalmış yorumcu geleneklerin geliştirdiği tortulaşmış okuma alışkanlıkları ve kategorileri aracılığıyla kavrarız. Jameson'ın önerdiği biçimiyle bu türden bir üstyorum yöntemi metin aracılığıyla okuduğumuz ve anladığımız yorumlayıcı kategorileri ya da kodları ön plana almalıdır (Jameson, 2011, s. 11). Bu bağlamda (öz)/Balkanlaştırma, oryantalist yaklaşım veya öz-egzotikleştirme pratikleri gibi açılar film metinlerinin okunmasında tortulaşmış yorumlama kodları ve eleştiriye açık kategoriler olarak kabul edilebilir. Politik bilinçdışı iddiası toplumsal bakımdan simgesel edimler olarak kültürel eserlerin maskesini düşürmeye yol açan çoklu yolları araştırmamızı önerir (Jameson, 2011, s. 20). Jameson, politik 
bilinçdışı yöntemiyle tarihselci bakış açısını sürdürürken, ideoloji ve öznellik üzerine olan sorgusunu edebiyat alanına çevirerek, örneğin Balzac, Gissing ve Conrad okumalarında oluşum halindeki kapitalizmde burjuva öznenin kuruluşunu ve onun kendi zamanımızdaki şizofrenik dağılışını yansıtır (Jameson, 2011, s.13). İdeoloji, bilinçdışı ve arzu, temsil, tarih ve kültürel üretim sorunsallarını anlatı çerçevesinde sorgular ve değerlendirirken, bu bakış açısının geleneksel diyalektik kod açısından sinema sanatını da içeren Darstellung (gösteri, canlandırma, temsil) araştırması olarak yeniden formüllendirilebileceğini vurgular. (Jameson, 2011, s.14). Özellikle Balkan coğrafyası olarak adlandırdığımız bölgenin güncel gerçeklerine bakılabilecek içeri açılan bir pencere, temsili bir kategori olarak sinema, Hırvatistan örneğinin savaş sonrası belirli bir döneminden oluşan araştırma evreni içinde inceleme alanı olarak seçilmiştir. Ulus devletleşme sürecindeki Hırvatistan sinemasının önerdiği veya eleştirdiği öznellik biçimleri, ideolojisi ve tarihselci bakış bağlamında Balkan sinemasını öncül okuma biçimlerine verilen iç-tepkiler çözümlemenin merkezindedir.

Iordanova da Balkan sinemasının bir araştırma alanı olarak hâlâ gelişmesi gerektiğini vurgular; bu eksikliğin sebebinin, söz konusu ülkelerdeki sinema geleneğinin değil, bölgedeki eğilimlerin farkına varacak akademik çalışmaların azlığına bağlar (Iordanova, 2007, s.25). Bu araştırma söz konusu eksikliği Hırvatistan sinemasının son 15 yıldaki tarihsel / ideolojik perspektiften araştırılmasını odağına alarak, uluslaşmaya ve daha sonra ise Avrupalılaşmaya doğru biçimlenen yeni Hırvat öznelliği üzerinden tartışmayı amaçlar. Batı sinemasında yaratılmış olan Balkan öznesi'nin karşısında, ulus devletleşmeden Avrupalılaşmaya giden süreçte, 2000-2015 yılları arası dönemde, çağdaş Hırvat öznelliğinin dramaturjik ve estetik olarak sinemada nasıl inşa edildiği, bu yeni öznelliklerin ve kimliklerin tarihsel, politik ve ideolojik boyutlarının neler olduğu, özellikle de öz-Balkanlaştırmaya bakışları, kendi kendini egzotikleştirmeden nasıl kaçındıkları veya öz-egzotikleştirmeyi yeniden üretme biçimlerinin bu yeni dönem sineması içinde nasıl gerçekleştiği sorularına cevap almak amaçlanmıştır.

\section{Savaş Sonrası Travmalar ve Kendini Yok Eden Özne}

$\mathrm{Bu}$ araştırma kapsamında Hırvatistan sinemasının 2000-2015 arasındaki dönemi içinde incelenmek üzere ele alınan filmlerin önemli bir bölümünde savaş öylesine geçip gitmiş bir tarihsel olay değil, birbirleri- 
nin yüzüne -ve hatta kendi yüzlerine de, bakarken birçok ana karakterin yeniden hatırladığı ve şimdi yüzleşmek zorunda olduğu yakın geçmiştir. Hırvatistan etnik temelli savaşın "kazanan" tarafı olarak tarihe geçmiş olsa da, sinema perdesine yansıyan karakterler bu yüzleşmenin ağırlıklı olarak savaş tarafından travmatize edilmiş yeni öznelerine yer verir, bir taraf için zaferle sonuçlanmış bile olsa savaşın sonuçlarını ve bireyler üzerinde yarattığı yıkımı tartışmaya açar.

Savaştan sonra yeniden yaşama devam edebilmenin tüm zorluğunun arkasında şimdi başka bir soru vardır: Bir zamanlar birlikte yaşadığımız öteki'mize tüm bunları yaptıktan sonra şimdi nasıl devam edeceğiz? Özneleşmenin koşulu olarak beliren ötekiyle yüzleşme kendine ait bir yer arayan -ve çoğu zaman bulamayan ana karakterin peşini bırakmaz: Kendilik ancak ötekiyle yüzleşerek ve onun yardımıyla yeniden kurulabilir.

Obrana i Zaštita'nın (Savunma ve Güvenlik, Bobo Jelčić, 2013) ana karakteri Slavko savaş sonrası travması içinde eylem yönünü kaybeden ve anlamsızlaşan öyküsünden kaçmanın yolunu arayan anti-kahraman örneklerinden biri olarak karşımıza çıkar: Savaş sonrasının bölünmüş toplumunda insanlar ve dostlar arasındaki görünmeyen sinırlar varl1ğını sürdürmektedir. Mostar'da yaşayan Slavko ölen Müslüman arkadaşının cenazesine gidip gitmemeye bir türlü karar veremez. Bu kadar masum ve doğal görünen bir eylem bile görünmez sinırlarla bölünmüş bir toplumda karmaşık ve zor bir karara dönüşebilmektedir. Eğer giderse tam da iş aradığı bir dönemde Hırvat toplumundan dişlanma olasılığı vardır, fakat gitmezse karısı onu eleştirecek ve kendisini dostunun ailesine karşı suçlu hissedecektir. Slavko sonunda cenazeye gider ve arkadaşının kızı Zehra'yı görme fırsatını bulur.

Savaş sonrası Hırvat özne, klasik bir dramatik karaktere dönüşmekten çok uzaktır, ne istediğini bilmez, ne yapması gerektiğine bir türlü karar veremez. Tam karar verdiği anda kendini tam tersini yaparken bulabilir. Nereye ve neden gittiği belirgin değildir. Bölünmüş toplum bölünmüş kişilikler yaratmıştır. Örneğin cenazeye gitmek kadar cenazeden nasıl dönüleceği de çözülmesi gereken büyük bir soruna dönüşür. Zehra onları evlerine bırakmak için, onlar da eve yürümek için ısrar edip dururlar. Gerilimli tartışmanın sonunda Slavko istediğinden yine vazgeçmiş ve Zehra tarafından eve bırakılmayı kabul etmiştir. Eve dönüş sahnesinde Mostar sokaklarından geçerken "her şey değişti, gidebilen herkes buradan gitmeli" der Slavko. Zehra ise aralarındaki bu 
sessiz gerginliğe daha fazla dayanamaz ve arabayı durdurup ağlayarak her şeye lanet eder. Savaş öncesinde birlikte yaşamış iki ailenin savaş sonrasında yaşadığı travmatik kopuş çocuklarına dek sirayet etmiş görünmektedir. Filmde ev ve sokak sekanslarının sonunda Slavko'nun önce kendini camdan attığını, daha sonra ise kendisine araba çarptığını izleriz. Fakat bunların hiçbiri gerçek değildir ve büyük ihtimalle karakterin kendisi için düşlediği sonlardan birkaçıdır. Slavko ölmez ve Mostar'daki evine döner, yaşamını sürdürmeye devam etmek zorundadır. Son sekansta ise bir ofisin bekleme odasında izleriz onu. Uzun bir sahne boyunca bekleyişi sürer ve film sona erer. Amaçsız karakterin varacağı nokta bir bekleme odası olmuştur. Birisi gelip onu çağıracak ve ne yapılacağını söyleyecektir. Slavko için en başta olduğu gibi en sonda da belirsizlik sürmektedir. Slavko'nun öyküsü savaş sonrası travması içinde kendisiyle ne yapacağını bilemeyen ve ötekiyle tekrar bir araya gelmenin yolunu kaybeden, bu yüzleşme olmaksızın da özneleşemeyen ve kendini tanımlayamayan bir öznellik biçimi üzerine kuruludur.

Slavko'nun öyküsünde bir olasılık ve düşlenen bir kaçış olarak duran "kendini yok etme" yine savaş sonrası travmaya odaklanan başka bir yapımda, Put Lubenica'da (Kavun Yolu, Branko Schmidt, 2006) bu sefer eski bir askerin öyküsünde somut ve kaçınılmaz bir sonuç olarak karş1mıza çıkar: Savaş sonrası Hırvat-Saraybosna sınırına yakın bir bölgede Sava nehri kıyısında yıkık dökük bir kulübede tek başına yaşayan Mirko, savaşı görmüş ve sahip olduğu tek ailesini, anne ve babasını savaştayken kaybetmiştir. Öykünün geçtiği 2005 yllında bulunduğu yerin yakınlarında açılan toplu mezarlarda onları bulmayı umut ederken, bir yandan Almanya'ya kaçak olarak geçmeye çalışan göçmenleri derme çatma teknesiyle Sava Nehri'nden geçirerek hayatta kalır. Bu yolun adı "Kavun Yolu"dur ve bu aslında göçmen trafiğini o bölgede idare eden çetenin taşıdıkları insanlar için kullandıkları gizli dilde "Göçmen Yolu" anlamına gelmektedir. Bu göçmen çetesi nehir kenarında gözlerden uzak kulübesinde münzevi hayatı yaşayan Mirko'yu koruyup kollayan, arada bir onu ziyaret eden bir sınır memurunun yardımıyla insan kaçakçılığı yapar. Savaştan kalma korkuları devam eden Mirko'nun savaşta kaybettiği tek şey ailesi değildir. Savaş deneyimi onu nerdeyse hiç konuşmayan, gece olunca ışığı açıp kapatarak uykuya dalabilen yalnız bir adam haline getirmiştir

Mirko, Almanya'ya yasadışı yollardan göçmek isteyen Çinli bir grubu taşırken derme çatma teknesi devrilir ve tüm kaçak göçmenler Sava Nehri'ne düşer. İçlerinden sadece bir genç kız kurtulacaktır. 
Mirko, babasını kaybeden ve doğada kimsesiz ve yalnız kalan Çinli kıza yardım etmek istemez. Yine de kız ona geri dönecek ve Mirko ona kapısını açacaktır. Ezilen, itilip kakılan ve sessiz Mirko'nun hayatında Çinli kızdan başka bir de çingene genç vardır. Her ikisini kurtarmak için -ki bu onların Almanya'ya kaçmalarına yardımcı olmaktır, savaş sonrasında sakladığı silahlarını çıkarır ve çetenin tüm üyelerini katleder. Mirko, kendini ve çevresinde savaş yıkımının üzerine kurulmuş olan yozlaşmış düzeni yok eden bir anti-kahraman olarak kalacaktır. Savaş sonrası travmanın Mirko'yu getirdiği nokta kendini feda ederek ötekiyi kurtarabilmek olarak karşımıza çıkar. Mirko anne ve babasının cesetlerinin bulunduğunu öğrendiğinde açılan toplu mezarlara gider, fakat cenazelerini almadan geri döner. Artık sürdürülebilir bir kimlik taşımaz, savaş sonrasında yeni bir yaşam kurmaya kalkışmaz, unutmayı da hatırlamayı da reddeder ve geleceğe kalacak bir anıt bırakmayacaktır. Bir özne olarak geriye kalan iki sevdiği insanı oradan kurtarmak ve daha Batıya kaçabilmelerine yardım edebilmektir, fakat kendisi için artık devam edilecek bir yaşam yoktur.

Kavun Yolu'nda, Balkan seyahat anlatısının tersine çevrildiğini kabul etmek de mümkündür. Balkanlaştırma yaklaşımında, batılı öznenin açısından daha doğudaki tekinsiz Balkanlar'a doğru yapılan yolculuk, bu sefer, kaçak göçmenlerin yolu olarak tanımlanmış, bu seyahatin yönü doğudan batıya doğru çevrilmiş ve coğrafyadan kaynaklanan tekinsizlik yerini savaş sonrasındaki yozlaşma olarak göstermiş fakat bu sefer içerden bir bakış açısından tanımlanmıştır. Ana karakterin geri döneceği güvenli bir evi yoktur. Onun savaştan sonra döndüğü evi, toplu mezarlarla dolu delik deşik bir yolun üzerindedir ve oradan başka bir yere gitmeyecektir. Fakat Çinli kız ve çingene için de güvenli ev Balkanlar'da bir yerde bulunmamaktadır. Hayatlarına devam edebilmeleri için Almanya'ya gitmeleri gerekmektedir. Mirko ile birlikte yeni bir yaşam kurma ve şimdi-burada mutlu olma şansları olamaz.

Fakat başka bir örnekte, bir Hırvat-Sırp ortak yapımı bir kara komedi olan Sedamdeset i Dva Dana'da (72 Gün, Danilo Šerbedžija, 2010) ana karakterin temel istemi taşradan kente göç etme yönünde şekillenir. 72 Gün'de babası, amcası ve kuzeniyle birlikte yaşadığı taşradan kurtulmak için sevgilisiyle birlikte Zagreb'e kaçmak isteyen Sirp kökenli bir genç, Branko ailesinden uzakta ve bağımsız bir hayat kurma düşü kursa da ailesinin kendisine yüklediği sorumluluk onun önünde engel olarak durmaktadır. Komşuları tarafından savaş sırasında kurtarılmış olan aile evinin başköşesinde ABD ordusunda aşçı olarak görev yap- 
mış ve artık hayatta olmayan dedelerinin fotoğrafı vardır. Büyükanne ise bakıma muhtaç ve Alzheimer hastasıdır. Dedenin ölümü aile için bir kahramanlıktır; çünkü hayatları boyunca hiç çalışmalarına gerek kalmadan, ABD'den büyükanne ye gelen maaşla geçinmektedirler. Fakat büyükannenin bakımını birlikte üstlenmişlerdir. İşsiz güçsüz genç Branko'nun hayalini gerçekleştirebilmesi için tek yol büyükannenin ölmesi ve amcasının onun payına düşen mirası kendisine vermesidir. Bir gün büyükanne ölür, fakat çılgın amca bu durumu her ay maaş ödemesi için kendisinden imza almaya gelen sarhoş postacıdan saklamaya karar verir ve tüm aileyi buna ikna etmeyi başarır. Trajikomik olaylar da bundan sonra başlayacaktır. Branko, artık Zagreb'e gidebilmek için kendi payına düşen parayı amcasından talep edebilir. Fakat yarı kaçık, sarhoş ve her an her türlü çılgınlığı yapabilecek bir Balkan figürü olarak çizilmiş olan amca Mane, ona yeni bir görev verir: Ailenin gelir kapısı büyükannenin ölümü gizlenecek ve huzurevinden büyükannenin yerine geçirilmek üzere yaşlı bir kadın kaçırılacaktır.

Aile üzerinde üstünlüğünü sürdüren amca Mane karakteri, ki bu karakter aynı zamanda Manchevski'nin Yağmurdan Önce'sinin (Before The Rain, 1994) ana karakteri Aleksander rolüyle Balkan kimliğini uluslararası alanda temsil etmiş ünlü Hırvat aktör Rade Šerbedžija tarafından canlandırılmıştır; tipik bir Balkan figürü olarak, Branko'nun hayatına devam edebilmesinin önündeki tüm engelleri yaratan çllgınca kararların, akıl almaz ve tüm aileyi felakete sürükleyecek olayların da kaynağıdır. Branko'nun kendi yaşamının öznesi haline gelebilmesi için aslında önce Batı sinemasında inşa edildiği haliyle Balkanlılaştırmanın ve öz-egzotikleştirmenin öyküdeki bir temsili olan amcasından kurtulması gerekecektir. Fakat amcası Mane aynı zamanda onun ailesidir, geçmişidir; geleneği ve taşralılığı temsil etmektedir. Çılgınca kararları en sonunda Mane'nin parasının peşindeki mafya üyesi iki adamı öldürmesi ve cinayeti örtmesine kadar uzanınca kimse buna dahil olmak istemeyecektir. Tüm grubu felakete sürükleyecek çılgınca kararları alan "amca"ya karşı, aile saygı duymayı ve itaat etmeyi bırakacak ve onun ani ölümü ile özgürleşebileceklerdir. Amca Mane, Dina Iordanova'nın Balkan Sineması: Alevler İçinde Sinema (2007) kitabında detaylı olarak tartışmaya açtığı, Zorba'da (Alexis Zorbas, Mihalis Kakogiannis, 1964), Yağmurdan Önce (Before The Rain, Milcho Manchevski, 1994) veya Yeraltı (Underground, Emir Kusturica, 1995) filmleri başta olmak üzere Balkanları konu edinen Batı yapımı sinemada defalarca yeniden üretilmiş olan, akıldan uzak, vahşi, sarhoş, çılgın Balkan stereotipini, her an her- 
şeyi yapabilecek bir deliliği temsil etmektedir. Film kendi hayatlarını kurmak ve özneleşmek isteyen karakterlerin Mane'nin arabasıyla savaştan kalma bir mayının üzerinden geçerek havaya uçmasıyla sonuçlanır. Alevler içinde yok olan aslında taşra ile de bütünleşen ve Batı'da çizilmiş olan Balkanlılık imajının temsilidir. Büyükannenin ölümü tıpkı Tito'nun ölümüyle dağılma sürecine giren Yugoslav Birliği gibi aileyi bir arada tutan ekonomik ve sosyal nedenleri ortadan kaldırmışsa da, Mane'nin ölümü de aile üyelerinin bireyleşmeleri, özgür ve özerk özneler olarak bir yaşam kurabilmeleri için onların yolunu açmıştır.

\section{Savaş Öncesi ve Savaş Dönemi Anlatıları}

İç savaş ve bölünme sonrası dönemin sinemasında savaş sonrası travmaların dışında savaş öncesi ve sırasındaki toplumsal ilişkilerin tartışmaya açıldığı bazı filmler de savaş sonrası öznelliğine dair fikirler vermeye yönelmiştir. Pavičić sürecin esasında edebiyat alanında başladığına dikkati çeker: "Doksanlı yılların sonuna doğru, daha önce egemenliğini sürdüren postmodernist edebiyat yerini savaşı, savaş suçlarını, uyuşturucuları, ev içi şiddeti de içeren toplumsal gerçekliği sert bir doğalcılıkla ele alan yeni bir stvarnozna proza (gerçekçi kurmaca) akımına bırakır" (Pavičić, 2011, s.7). Her ne kadar edebiyat alanında yaşanan bu dönüşüm, hem postmodernistlerin hem de gelenekçilerin eleştirilerine maruz kalsa da, sinemacılar için önemli bir başvuru kaynağına dönüşür. Bunlardan biri olan Karaula (Sinır Karakolu, Rajko Grlić, 2006) mizahi romanlar yazan bir yazar olan Ante Tomić tarafindan yazılmıştır. Sınır Karakolu, Hırvat bir yönetmen tarafindan yönetilmiş olsa da eski Yugoslav Birliği üyelerinin tamamı tarafından desteklenmiş ilk ortak yapımdır aynı zamanda.

Farklı etnik kimliklerle tanımlanmış karakterlerin etkileşimlerini eleştirel biçimde ve mizahileştirerek sorunsallaştıran Sınır Karakolu'nun öyküsü savaş öncesinde fakat savaşa tarihsel olarak oldukça yaklaşılan bir dönemde, 1987 yılında, Ohrid Gölü yakınlarında, Yugoslavya- Arnavutluk sınırındaki bir sınır karakolunda geçer. Yönetmen Grlić filmi kısa bir açıklamayla açma gereği duyar:

Yugoslav Ordusu 2. Dünya Savaşı sırasında komünist lider Mareşal Tito tarafindan kurulmuştur ve 50 yll boyunca bu ordu çok etnisiteli Yugoslavya'nın sembolü olmuştur. 18-27 yaş arası tüm erkekler en az bir yll boyunca bu çok etnisiteli birliklerden birinde hizmet vermek zorundadır. 
Henüz duvar yıkılmamış, komünist sistem ve Yugoslav toplumu resmi olarak dağılmamıştır. Fakat ordunun en önemli ve somut simgesi olarak işlev gördüğü Birlik üyeleri birkaç yıl içinde kanlı bir savaşın tarafları olacaktır. Tarihin böyle bir noktasında Tito'nun Yugoslavya'sını komünizm karşıtı arkaik dış düşmanlarından korumak için bir araya gelmiş askerlerden oluşan bu askeri birim, genel toplumsal kümenin daha küçük ve anlamlı bir metaforu olarak kurulmuştur. Sınır karakolu, bir yandan komünist Yugoslavya'yı Arnavutluk tarafindan her an gelebilecek bir saldırıdan korurken diğer yandan kendi içlerinde yaşadıkları çatışma ve ilişkiler bütünüyle toplumsal alandaki etnik bölünmeyi yaratacak olan çatlakların izlerini ele verir. Henüz kimsenin yakın gelecekte yaşanacak olan iç savaştan ve etnik temizlikten haberi yoktur ve onları bir arada tutan esas düşman / ortak öteki o sırada sınırın diğer tarafinda yer alan Arnavutluk'tur.

Askerler birkaç yıl sonra belki birbirlerini öldürmek için cepheye çıkacaklardır fakat henüz bunu bilmezler. Kaçınılmaz olarak, karakterler arasındaki tüm çatışmalar, bu bilgi ışığında sürekli yeniden kurularak filmi izleme deneyimini daha katmanlı hale getirir. Böylece, Yugoslav Birliği'ni oluşturan etnik parçaları temsil eden karakterler -tıp eğitimini henüz tamamlamamış Dalmaçyalı / taşralı, Hırvat kökenli, uçarı genç er Siniša, alkolik ve kolayca kandırılabilen, sert görünümü altında zavallı ve saf bir adamın çizildiği Bosnalı komutan Safet, hayatı ciddiye almayan, şakacı ve komutanından yediği tokadın intikamını acı bir şekilde almaktan çekinmeyen Sırp kökenli er Ljuba; zaman çizgisinde geleceğe doğru yönelmiş bir tarihselleştirme içinde sürekli bir okuma eşliğinde gelişirler. Komutan Safet ve onun emri altındaki Siniša ile gizli bir ilişki yaşayan karısı Mirijana'nın ölümü ile sona eren trajik öyküden sağ kurtulanlar yine Hırvat ve Sirp erler olur. Safet'i öldüren ise komutanından yediği tokadın intikamını alan Sırp Ljuba'nın nefret dolu darbeleri olur. Hırvat Siniša ise hem Bosnalı komutanı hem de yasak bir aşk yaşadığı karısını kurtarmak isteyecek fakat çok geç kalacaktır. Hatta daha sonra cinayeti işleyen Sırp arkadaşını korumak için susacaktır. Sınır Karakolu'nun başlangıçtaki mizahi anlatısı, filmin sonunda trajediye dönüşür. Gündelik şakalaşmalardan oluşan masum çekişme ve çatışmalar, örtbas edilecek kanlı bir cinayetle sonuçlanır. Filmin başındaki renkli dünya sonunda gecenin karanlığına döner.

Sınır Karakolu, filmin açılışında olduğu gibi kısa bir açıklama ile biter: "Arnavutluk hiçbir zaman Yugoslavya'ya saldırmadı. Dört yıl 
sonra Yugoslavya kendi ulusları arasında yaşanan bir dizi kanlı savaşla çöktü". Toplumsal birliğin ve komünist rejim altında inşa edilmeye çalışılan dostluk ve kardeşliğin sorgulandığı Sınır Karakolu'nda, kendini öteki üzerinden inşa etme fikrinin sürdürüldüğü, ayrıca iç savaş ve yarattığı travmanın savaş öncesi bir dönem üzerinden ele alındığı gözlemlenir. Karakterlerin farklı etnik kökenleri içinde kurgulanmış kimlikleri, toplumsal düzlemde yaşanacak çatışmaların taraflarını temsil edecek şekilde çizilmiştir.

İç savaşın ilk yılında Hırvat bir özel askeri birliğin düzenlediği bir kurtarma operasyonunu konu edinen Crnci (Siyahlar, Zvonimira Jurić \& Goran Dević, 2009), Sinır Karakolu'nun son sekanslarında Bosnalı komutanla karısının öldürülmeleriyle ulaşılan trajik ve karanlık sonun kaldığı yerden başlar gibidir. Yine bir grup askerin bir nedenle bir araya geldiği bir öykünün son sahnesi, bu sefer filmin açılış sahnesi olarak seçilmiştir. İlk sahnede kurtarma amacıyla yola çıkan ekibin kendini yok ettiğini izleriz. Filmin geri kalanı onları bu noktaya getiren önceki 24 saatte olanların dizgesinden oluşur ve operasyona hazırlık sürecindeki ilişkilerine geri dönüş yapar. Birliğe sonradan dâhil edilen Barišić aslında savaşı bir macera olarak görmüş, yalan söyleyerek ${ }^{2}$ birliğe katılmıştır. Fakat bodrum katta girilmesi yasak bir odada gizlenmiş savaş suçlarının kanıtı işkence izlerini görmesi ile kapana sıkışmış hissetmeye başlayacaktır. Bir başka asker ise (Franjo) işkence tanıklıkları sonucunda eroin bağımlısı haline gelmiştir. Komutan Ivo dâhil olmak üzere her biri tipik savaş kahramanı olmaktan uzak, sorunlu kişiliklere, eli kanlı katillere dönüşmüşlerdir. Barišić karargâhın karanlık bodrum katına indiğinde Franjo bir an için ışığı yakıp hemen arkasından söndürür. Bu çok kısa zaman dilimi içinde burada işlenmiş cinayetlerin gösterenleri olarak duvarlardaki kan izleri bir an görünür ve hemen sonra karanl1ğa gömülür. Bodrum katın karanlıklarında bir an için aydınlanan savaş suçları ve savaşın karanlık yüzü toplumsal bilinçaltının yine bir an için bilinç düzeyine çıkarılmasını sağlar. Fakat yine de yüzleşme başlamıştır; hem Barišić karakterinin dönüşümünde, hem de suçun fail tarafında yer alan Franjo'nun sorunlu ve tekinsiz zihninin doğrulanmasinda.

Pavičić'e göre, yönetmenler öykünün kronolojik sözdizimini değiştirerek, sinematik makineyi izleyiciye karşı doğrultmuşlardır (Pavičić, 2011). ${ }^{3}$ Özellikle klasik bir savaş filmi olarak başlayan Siłahlar şok

\footnotetext{
2 Savaş öncesinde madenci olduğunu ve bölgeyi tanıdığını söylemiştir.

3 İnternetteki kaynakta sayfa numarası yer almamaktadır.
} 
edici ilk sahneden sonra, savaş suçlarıyla ve savaşın askerler üzerinde yarattığı fiziksel ve zihinsel yıkımla yüzleşilen klostrofobik ve karanlık karargâh binasının içine sıkışır. Öyle ki, savaşın her bir asker üzerinde yarattığı yıkım en sonunda kurtarma amacıyla yola çıkan birliğin öz-yıkımıyla sonuçlanır. Henüz savaş bitmemiştir fakat birlik üyeleri, Kavun Yolu'nda yine Mikić tarafindan canlandırılmış olan Mirko veya Savunma ve Güvenlik'te Slavko'nun kendisi için düşlediği intihar olasılıklarında olduğuna benzer bir kendini yok eden özne durumuna ulaşırlar. Pavičić, bu tersine çevrilmiş kurguyu 2000 ve 2010 yılları arasında Hirvat toplumunun ulusal bilincinde gerçekleşen mutasyonun bir karşllığı olarak görür (Pavičić, 2011). ${ }^{4}$ Filmin, ormanda ilerleyen askeri birliğin kesik takipleriyle oluşturulmuş kurgusu gerçekten de savaş dönemi televizyon ekranından çıkmış gibidir. Savaş suçlarıyla yüzleşme dönemi ise aynı zamanda toplumsal bilinçte -Franjo'nun ışığı bir an için açıp kapatmasının etkisinde olduğuna benzer bir şekilde, Avrupalılaşma sürecinin bir parçası olarak gerekli olmuştur.

\section{Alt-Ötekiler ve Üst-Ötekiler Arasında Bir Yerde Yeni Hırvat Özne}

Çok kültürlü ve çok etnisiteli toplumun siyasal alanda çözülmesi ve yeni sınırlar etrafında yeni ilişkiler inşa edilmesi, elbette geçmişin toplumsal ilişkilerinden ve her toplumsal grup için ötekinin konumundan bağımsız olamazdı. Vojković'in Armin (Ongjen Sviličić, 2007) incelemesinde, Žižek'in Balkan tanımından yola çıkarak vurguladığı gibi bir öteki olarak Balkanlı özne hep biraz daha güneydoğuda yer alandır. Bosnalı ve Müslüman bir genç olarak Armin, Alman yapımı bir filmin oyuncu seçmelerine katılmak üzere babası tarafından Zagreb'e getirilir. Modern bir kent olarak Zagreb burada taşradan gelen Armin ve babası için Batı'yı temsil eder. Üstelik Zagreb'de ceplerinde her gün azalan paralarıyla bir otelde kalmak zorundadırlar. Babası İbrahim oğlunun müzikteki geleneksel ve otantik yeteneklerinin onun daha Batı'da kabul görmesini sağlayacağı umuduyla Zagreb'e gelmiştir. Tam da bu noktada öz-oryantalizm ve öz-egzotikleştirme ortaya çıkar (Vojković, 2008, s.89). Çünkü baba İbrahim akordeonuyla geleneksel müzikler çalan oğlunu bir Balkan öznesi olarak gönüllü bir biçimde Batılının görüş açısına sokmaya çalışır. Fakat Armin seçmeleri kazanamaz, üstelik yaşadığı epilepsi krizi nedeniyle yeteneğini gösteremez ve şansını kaybeder. Fakat bu durum Armin için yeni bir olanak açar ve Alman yönet-

4 İnternetteki kaynakta sayfa numarası yer almamaktadır. 
men artık gitmekten başka seçeneği kalmayan Armin'e Saray-Bosna ve savaş hakkında bir belgeselde yer alması için teklifte bulunur. Özellikle de iç savaş döneminden kalmış olabilecek hastalığı Armin'i yönetmen için daha ilginç hale getirir. Fakat Armin bunu kabul etmez. En başından beri oğlunun filmde oynaması için ısrarlı baba da artık oğlunu ikna edemeyeceğini söyler: Çünkü o artık çocuk değildir. Armin gerçekten de çocukluktan yetişkinliğe geçişin eşiğinde bu kararı vermiştir. Böylece sadece kendi kararını vererek babasından bağımsızlaşmaz, aynı zamanda Balkan özne olarak konumlanmayı da reddederek yeni kimliğinin arayışına koyulur. "Armin gibi, Balkan öznesi de büyümekte ve kendi koşullarında tanımlanmayı talep etmektedir (...) En somut haliyle, tüm tezatlara karşın, bu bölgelerde bireyin kendi öznelliğini ve kimliğini inşa etme potansiyeli bulunmaktadır" (Vojković, 2008, s.91). Alman yönetmen ve ekibinin merkezi konumu ve çevre/taşradan bu merkeze doğru çekilen Bosnalı'nın modern kent yaşamına katılma talebi bu iki kimliği Zagreb arka planında karşılaştırır. Bu karşılaşma, daha Batı'dan gelenle daha Doğu'dan, daha doğrusu Güneydoğu'dan gelenin karşılaştığı bir köprü üzerinde gerçekleşir. Zagreb bu köprüdür; tıpkı Kavun Yolu'nda Çinli göçmen kadın ve çingeneyi Sava Nehri üzerinden Almanya'ya taşıyan tekne gibidir, ve Balkan coğrafyasının bir yolculuk ve karşılaşmalar topografyası olarak yeniden kurulmasına sahne olur. Armin'de bu karşılaşma üst ve alt kimlik konumlarının çatışmaları şekline bürünür bu kez.

Alman ve Bosnalı / Müslüman kimliklerinin arasında bir yerde konumlanan Hırvat öznelliğinin tartışmaya açıldığı bir başka filmdes, Šuma Summarum'da, (Orman Yaratıklarl, Ivan-Goran Vitez, 2010) içinde farklı etnik kimliklerin olduğu bir grubun öyküsü kara komedi tarzında karşımıza çıkar. Orman yaratıkları, farklı etnik, milli veya dini arka planlara sahip karakterlerden oluşur. Öyle ki önce iş arkadaşları olarak yola çıkan ve bir hafta sonunu ormanda paint ball oynayarak geçirmekten başka bir amaçları olmayan bir grup, çalıştıkları şirket tarafından tuzağa düşürülür. Çünkü şirket yönetimi işten atıldıklarında yüklü sigorta ücreti ödenmesi gerektiği için çalışanlarını bir hafta sonu

5 Alman kültürü ve kimliğinin bir üst-öteki olarak kurulduğu bir başka film olan, Tomislav Radić'in Što je Iva Snimila 21.10.2003? ( Iva 21.10.2003'te Neyi Filme Çekti?, 2005) adlı filmi de bu kategoride izlenmesi gereken önemli bir örnektir. Vojković (2008) tarafından detaylı bir biçimde incelenmiş olduğundan bu araştırmanın kapsamı dışında tutulmuş olsa da, Alman-öteki ve modern Balkan öznesi arasındaki çatışmalı ilişkiye daha yakından bakmak isteyen bir göz için okuma/izleme alanına rahatlıkla eklenebilir. 
etkinliğine çıkararak ormanda tuzağa düşürüp öldürmenin daha kârlı olacağını düşünmüştür. Bu planı gerçekleştirmek için ormanın içinde medeniyetten uzak yaşayan karikatüristik hatlara sahip bir aile tasviri ile paint ball alanının sorumlularını taşralı işbirlikçileri olarak seçer ve çalışanlarını öldürmeye başlar.

Orman içinde ellerinde oyuncak silahlarla ne yapmaları gerektiğine karar vermeleri gerektiği anlarda kimi zaman düşman haline gelen şirket çalışanları arasındaki hiyerarşi içinde dikey ve yatay ilişkilerde etnik ayrımlanmanın sürekli vurgulanan etkisi hissedilir. Örneğin grubun ormanda güvenli bir şekilde ilerlemesi sorumluluğu bir Alman'a verilmiştir. Topluluğun bir sonraki adımının ne olacağına karar verecek olan Alman üst-öteki olarak konumlanır. Grupta bir tartışma olduğunda Alman lider grup üyelerini hiçbir şeyi beceremeyen, topluluk halinde birlikte tek adım atamayan insanlar olarak tanımlar. Bosnalı Müslüman şirket çalışanı, yeri geldiğinde kolayca bağnazlıkla itham edilir. Çünkü korktuğu zamanlarda aklına değil, duaya sığınarak, gelenekle bağını sürdürmekte ve böylece asla karar veren bir merkez konumu olarak kurulamayacağının işaretlerini vermektedir. Yine de Hırvat arkadaşları tarafından ölene dek korunup kollanacak, yaralarına rağmen taşınacaktır.

Ormanda yaşayan işbirlikçi taşralı aile ise tamamen kötüye dair her şeyi temsil eder, sürekli öz ağabeyinin cinsel tacizinden kendini korumaya çalışan ve kitap okumaktan başka bir şey yapmayan genç kız dışında. Genç kızın kurtuluşu ormandan ve ailesinden kurtulmak, kente ulaşmak olacaktır. Fakat o da şirket çalışanları gibi ormandan çıkamaz ve kurban haline gelir. Tüm bunların yanında yaşanan katliamdan habersiz ormana mantar toplamaya gelmiş feminist kadın ve onun aşağılama ve acımasız komutlarına medeniyet adına itaat etmeye devam eden sevgilisi vardır. Feminist, çevreci ve modern çiftin taşralı ailenin anne karakteriyle karşılamaları ilginçtir. Taşralı kadın tamamen ev işleri, çocukları, kocası, sırtında ve karnında taşıdığı bebekleriyle ataerkil sistemin içinde sorgulamaksızın ve hatta onu üreterek yaşamaktadır. Kentten gelmiş çevreci / feminist çifti ormanın ortasında tartışırken görür. Kadın erkeğe sözleriyle saldırmakta ve onu aşağılamaya devam etmektedir. Taşralı bu duruma dayanamaz ve erkeği kurtarmak için sonunda kentli kadına saldırır, kentli kadın ise tüm medeniyetine rağmen kurtulabilmek için erkeğin yardımını çağırır. Erkek tüm hırsını ve birikmiş öfkesini hamile taşralı kadını vahşice döverek ve öldürerek 
sonlandırır. Feminist kentli kadın ise kurtulmak için buna ses çıkaramayacaktır.

Topluluk haline gelme ve birlikte ilerlerken, bir diş düşmanın tuzağına düşerek birbirini katletme, düşmanın kim olduğunu bilememe ve arka plandaki büyük oyunun içinde kaybolma gibi temaları izleyen Orman Yaratıkları parçalanmış ve birbirini katletmiş bir toplumun modern yüzünü, daha doğrusu savaş bitse de hala çatışma halinde olan alt/üst ötekileri de içeren stereotipileriyle ikiyüzlülüğünü tartışmaya açar. Söz konusu olan, kapitalist canavarın saldırısına uğrayan toplumda bölünmüşlük ve kaybedilmişliktir. İş arkadaşlarını ormanın içinde düşman haline getirip, birbirine kırdıran aslında içinde bulundukları ve eninde sonunda yüzleşmek durumunda kalacakları kapitalizm olmuştur. Bunu fark etmek zaman alacaktır ve bu zaman içinde pek çok masum insan / iş̧̧i hayatını kaybedecektir. Orman yaratıklarından sadece geri kalan birkaç kişi kente dönebilir, tüm cinayet planını kurgulayıp sahneye koymuş olan Alman patron da gecenin karanlığında kente doğru yaralı halde bir bisikletle dönecektir. Filmin son karesi, karanlıkta parlayan kentin ışıklarına doğru tüm gücüyle pedal çeviren Alman patronun yüzünü gösterir. Aslında asıl orman kenttir ve av orada devam edecektir.

Kendi öznelliğini öteki üzerinden kurma ama bu sefer alt ve üst ötekiler arasında bir öznellik konumuna yerleşme; yine, birlikte olamamanın kendini ve ötekini yok etmeyle sonuçlanması... Kentliye karşı taşralı, eğitimliye karşı eğitimsiz, kadına karşı erkek, işçiye karşı patron, farklı etnik köken ve milliyetlere sahip kişilerin birlikte hareket etme güçlüğü ve kapitalist sisteme geçmiş bir toplumun bu yeni sistemin karanlık tarafıyla yüzleşmesi Orman Yaratıkları'nda gündeme gelir. Benzer grup dinamikleri Kauboji'de (Kovboplar, Tomislav Mršić, 2013) bu kez amatör bir tiyatro topluluğu oluşturmak üzere bir araya gelmeye çalışan farklı özneler arası ilişkilerde yeniden kurulur.

Kovboylar'ın anlatısı yine kentten uzaklaşan ve sanayi bölgesinden geçen bir arabanın yolculuğu ile başlar ve kültürel anlamda çölden farksız bir taşra otelinde kurgulanır. Sorunlarından ve dolayısıyla kentteki yaşamından kaçan tiyatro yönetmeni Saša, bu her şeyden uzak yerde bir tiyatro grubu kuracaktır. Annesiyle yaşayan Javor, hapisten yeni çıkmış işsiz güçsüz ve güvenilmez Ivan, mafyayla başı belada, sokakta parfüm satarak geçinen Miodrag Osmanović, uyuşturucu bağımlısı Domagoj, geçmişi belirsiz ve nerdeyse hiç konuşmayan sert görünüm- 
lü bir işçi olan Bruno, akli dengesi bozuk kardeşler Marica ve Jura, bu tiyatro grubunun yeni oyuncularıdır. Kentten kaçarak taşraya gelmiş entelektüel Saša bu işe yaramaz ve tutunamamış insanlardan bir tiyatro grubu çıkarmayı deneyecektir. Saša birbirinden ayrı tutunamayan bu insanları bir topluluk haline getirmeyi başarır, fakat yakalandığı kanser nedeniyle oyunu izleyemeden ölür. Topluluk liderini kaybedince dağılmaya yüz tutsa da, Saša ölmeden onları bir arada tutacak sloganı tekrarlar: Çalışarak birlikte kalacaklardır. Bu slogan hastane duvarlarında defalarca yankılanır. Kovboylar'ın anlatısı Yugoslavya'yı ve birbirinden ayrı etnik grupları bir arada tutan Tito'yu anımsatır. Tito'nun 1980 yılındaki ölümü sonrasında Yugoslavya'yı bir arada tutan figür artık yok olmuştur. Topluluk olarak kalmak için çaba harcanması gerekecektir. Fakat tarihsel olaylar Kovboylar'daki gibi iyimser yönde gelişmez. Tito'nun varlığından daha fazla yokluğunun toplum üzerinde yarattığı etkiyi Iordanova gündeme getirir: Tito'nun ikonik ve birleştirici baba rolünün inşasında etkili olan ve yaşamı boyunca çekilmiş yüzlerce görüntüsü içinde en çok sömürüleni, içinde kendisinin var olmadığ 1 görüntüsüdür. Tito'nun bedeninin Ljubljana'dan Belgrad'a taşındığı ve sonunda cenaze törenine yönelmiş bir tren yolculuğunun görüntülerinden oluşan bu filmde ağlayan binlerce insan liderlerine veda etmek üzere demiryolu kenarlarına koşarlar (Iordanova, 2007, s.125-126). Çözülme baba figürünün birleştirici varlığının son bulmasıyla başladığı için, Tito aslında öldüğü için suçludur. ${ }^{6}$ Fakat Saša'nın onlara verdiği son öğüt tiyatro topluluğunu kurtarır ve yaşadıkları tüm aksiliklere rağmen yönetmenleri olmadan oyunu sahneye koyabilirler.

Ötekilik Kovboylar'da kent-taşra ekseninde entelektüel Saša'nın taşralı grup üyelerini eğitme çabası içinde belirse ve etnisite çok fazla konuşulmasa da bir noktada "Sen kimsin?" sorusu üstü hemen kapanmak üzere Domagoj ve Miodrag arasındaki küçük bir diyalogda gündeme gelir. "Yoksa sen Sirp mısın?" diye sorar Domagoj; "Hayır Sirp

6 Iordanova Želimir Žilnik'in, Tito'nun ölümü sonuncunda artık var olmayan baba figürünün kullanımını sorguladığı Tito po drugi put među Srbima (Tito İkinci Kez Sırplar Arasında, 1994) adlı mockumantary türünde çekilmiş filmi üzerinden tartışır. Tito'nun ölümünün üzerinden 14 yll geçmiştir. İkonik lideri canlandıran tanınmış Tito taklitçisi oyuncu Dragoljub Ljubičić, müzeden Mareşal kostümüyle çıkar ve Milošević'in Belgrad'ının sokaklarında dolaşmaya başlar. İnsanlar bu oyunu fark ederler fakat yine de oyuna katılırlar ve pek çoğu onu Yugoslavya'nın geldiği durumun suçlusu olarak görür: "Neden ben?" "Çünkü öldünüz". Terk edildikleri için kızgındırlar. Tito ise sonunda onların sorunlarına cevap veremeyeceğini anlar ve en iyisinin müzedeki yerine dönmek ve huzur içinde yatmak olduğuna karar verir (Iordanova, 2007: 127). 
değilim, neden?" cevabını alır hemen. "Tamam korkmana gerek yok" dediğinde ise Miodrag, "Biz Sırplar korkmayız" der ve ekler, "yarı Çingene, yarı başka bir şeyim... Peki sen?" Domagoj'un yanıtı "Ben normalim" şeklinde olacak ve bu sıkıntılı konu bir daha açılmamak üzere kapanacaktır. Normun ne olduğu fazla karışmamış olmakla ilişkilidir. Çingenelik ise çok da gururla dile getirilen bir kimlik olarak durmaz. Balkanlar üzerine yapılan pek çok filmde kültürel kimlikleriyle defalarca tasvir edilmiş ve şablon haline getirilmiş Çingeneler (Romanlar), "bütün Balkan topraklarına yayılmışlardır ve mevcut hiçbir 'ulus devlet'e ait değildirler" (Iordanova, 2007, s.277). Iordanova'nın da belirttiği gibi Çingeneler çoğu zaman egzotik olarak betimlenirken, hiçbir zaman yaylmacı ve merkezi bir iktidar talebinde bulunan tehdit edici bir azınlık olarak görülmediklerinden doğal, gelenek dışı rahat davranışları içinde ve genellikle dişardan temsil edilmişler fakat bu betimlemelerde marjinallikleri olumsuzlanmamıştır. Alt-ötekiler olarak Çingeneler, Gramsci'nin subaltern kavramını yeniden gündeme getiren Gayatri C. Spivak'ın kendi sesi olmayan, fakat resmi ve egemen olanın diliyle temsil edilerek sessizliği daha da derinleştiğini söylediği madunlardır. Kendi kendini temsil edemeyen madun politik olarak "adına konuşulan"dır. (Spivak'tan aktaran Sönmez, 2014, s.37). "En alttakiler, madunlar öyle bir konumdadırlar ki, öylesine kenarda kalmışlardır ki sesleri yoktur. Sesleri baskın kültür ve dil tarafindan öylesine parçalanmış ve ayrılmiştır ki duyulmaz" (Süalp'ten aktaran Sönmez, 2015, s.36).

Çingene temsilinin birleştirici bir unsur olarak yer aldığı Nije Kraj'ın (Burada Bitmeyecek, Vinko Brešan, 2008) merkezinde âşı olduğu Sırp kadını bulmaya çalışan Hırvat gencin öyküsü bulunur. Senaryo yazarı Mate Matišić ile yönetmen Vinko Brešan, Hırvat olsa da film Hırvat-Sırp ortak yapımıdır. Savaş döneminde askerken silahının dürbünüyle uzaktan izlediği Sırp kadına âşık olan Martin, savaş sonrasında kadının (Neda) izini kaybetmiş; ancak günün birinde bir porno filmin içinde hüzünlü yüzünü tanımıştır. Savaş sonrasında köyü yıkılan ve kocası öldürülen Neda'yı Çingene dostu Djuro'nun yardımıyla bulup onu kurtarmaya çalışacaktır. Oysa savaş ve ondan sonra yaşadıkları Sırp kadının hafızasını ve kimliğini silmiş gibidir. Martin sevdiği kadını alıp kendi evine getirse de hiçbir şey beklediği gibi olmaz, savaş öncesindeki gibi normal bir ilişki kurabilecek sıradan insanlara dönüşemezler. Savaş sonrası travma içinde yaşamını yeniden kuramayan öznenin iki farklı örneği olarak tüm dış çatışma unsurlarını yenseler de, bir arada kalamazlar. Yine de Çingene Djuro onları kendi mahallesinde bir araya 
getirmeyi başarır ve bir arada kalmaları için bir Çingene düğünü düzenleyerek Hırvat ve Sirp karakterlerin imkânsız ilişkisini sağlayacak bir harç işlevi görmek için gönüllü olur.

\section{Gelenek ve Modern Arasında Bir Başka Öteki: Kadın Özne}

Hırvat sinemasının özellikle savaş sonrası travmasıyla ilişkili bölümü erkek karakterin merkezinde olduğu öyküler ile gündeme gelmişse de, kadın karakterin ikincil olmaktan kurtulduğu ve merkeze girdiği örneklerde, gelenek ve modern arasında bir yerde kentli kadının öznelleşme mücadelesi öne çlkmaktadır.

Savaş döneminde ve hemen sonrasında üretilen filmlerde Yugoslavya'dan bağımsızlık sürecinde yeni Hırvat devleti, yeni Hırvat kadını ve Hırvat erkeğinin görüntüsünü formüle etme gereksinimindeydi. Bedeniyle yeni etnik toplumu oluşturacak bireyleri üreten kadın aynı zamanda ideolojik yeniden üretimin merkezi figürü oldu (Simić, 2011).7 Sinemadaki temsiliyeti açısından bakıldığında, savaş boyunca bir taraftan ziyan edilmiş, tecavüze uğramış, toplumu tarafından istenmeyen çocuklara gebe kalmış kadın bedeni, ulus devletleşme ve bağımsızlık döneminin ideolojik yeniden üreticisine kolaylıkla dönüşür. Ulus devletin inşasında kendisine önemli geleneksel roller düşen kadın, Avrupalılaşma döneminin getirdiği modernleşme sürecinde yeni bir öznellik kriziyle karşı karşıya kalır. Savaş geride kalmış ve yeni Hırvatistan için kazanılmıştır. Yeni kapitalist sistemde kadın için ev ile sokak, aile ile bireylik karşı karşıyadır. Majka Asfalta'da (Asfalt Annesi, Dalibor Matanić, 2010) kocasından gördüğü şiddet ve sevgisizlikten kaçan Mare giderken yanına küçük oğlunu da alır. Mare, giderken oğluna büyük bir maceraya çıktıklarını söyler. Gidecek bir yerleri olmadığından bir alışveriş merkezinin otoparkındaki arabalarında kalırlar. Fakat Mare'nin oğluna sözünü verdiği macera onlar için felakete varacak tekinsiz bir yolculuk haline gelir. Alışveriş merkezinin gece bekçisinin dikkatini çekerler ve sonunda ona güvenerek soğuk geceyi arabada geçirmek yerine alışveriş merkezindeki satılık koltuklardan oluşan dekorda kalmaya başlarlar. Fakat ilk başta bir sığınak gibi görünen ve onlara aradıkları mutlu ev dekorunu sunan bu mekân bir süre sonra güvenliklerini tehdit eden bir labirent haline gelecektir, çünkü güvenlik görevlisinin sessiz görünümünün altından kadının aradığı şefkat yerine saldırgan bir zihinsel bozukluk çıkacak, böylece Mare ve oğlu onun hedefindeki kurbanlara

7 İnternetteki kaynakta sayfa numarası yer almamaktadır. 
dönüşecektir. Alışveriş merkezi bir tuzaktır ve artık oradan kurtulmak, sonunda sıcak yuvalarına dönmek için mücadele vermek zorundadırlar. Yine de Mare bu tuzaktan tek başına çıkamaz, yokluğunda onu en yakın arkadaşının karısıyla aldatmış olan kocası sonunda hatasını anlayarak onları bulacak ve kurtaracaktır. Kahramanın yolculuğu kesintiye uğrar ve kadın karakter mücadeleler sonunda kendini yeni bir özne olarak kuramaz. Başladığı noktaya, kaçtığı eve, kocasına ve geleneğin güvenli alanına geri döner.

Mare'nin gerçekleşemeyen kahramanlık öyküsünün bir benzeri Fleke'de (Lekeler, Alda Tardozzija, 2011) bu sefer ergenlikten genç bir kadın olmaya geçme eşiğindeki Lana ve Irena'nın Zagreb'in tekinsiz sokaklarında geçen öyküsünde karşımıza çıkar. Lana genç bir kadındır ve tüm istediği ailesinin katı kurallarından kaçarak dışarda sevgilisiyle bir gece geçirebilmektir. Buna karşın Lana'nın bu isteği sevgilisi tarafindan bir taksinin arka koltuğunda tecavüze uğraması ve bekâretini kaybetmesiyle sonuçlanır. Irena ise Lana'nın aksine bir aileye sahip değildir. Bir takside soygun yaparken taksi şoförünü öldürür. İki genç kadının da giysilerinde artık kan lekeleri vardır ve masumiyetlerini yitirmişlerdir. İkisinin yolları bir gece kulübünün tuvaletinde kesişir ve kimliklerini, dolayısıyla lekeli kıyafetlerini değiştirerek birlikte bir gece sürecek bir maceraya çıkarlar. Yolun sonunda Irena kazara ölecek ve Lana Zagreb'in tekinsiz sokaklarından en başta kaçmaya çalıştığı güvenli evine ve ailesine geri dönecektir. İki genç kadın bir gece için birbirlerinin yerini alır, Irena gerçekte bir aile istemekte Lana ise ailesinden uzaklaşarak bireyleşmek istemektedir. Ailesiz Irena zaten yok olacak, Lana tüm maceranın sonunda annesinden gelen telefonla kendi giysilerini giyip evine geri dönecektir.

Hem Lana hem de Mare karakterlerinin öyküsünde aileden koparak birey olmaya doğru bir maceraya çıkan kadınlar tekrar aile çatısına geri döner. Ulus devletin en küçük parçası olan aile ile temsil edilen geleneksel alandan, modernitenin en atomize birimi bireyliğe geçiş yolculuğunda, kadın öznenin mücadelesi her iki kadın karakter için de ailedeki rolüne geri dönüş ile sonlanır. Erkek öznenin savaş sonrasında geçirdiği travmatik aşama öznelleşme mücadelesine girmeyi tümüyle reddetmesiyle temsil olunurken, kadın öznenin bireyleşme için girdiği macera yolundaki engeller aşılsa da öyküler dairesel bir biçimde kendi içine kapanarak, başlangıç noktasında son bulur. Gelenek ile modern arasındaki öznelleşmenin imkânsızlığl; kapitalist sisteme geçmiş toplumda kadının yine ataerkil aile düzeninden başka bir sığınak bulama- 
ması söz konusudur.

Asfalt Anne'nin yönetmeni Dalibor Matanić'in daha önce çekmiş olduğu 2002 yapımı Fine Mrtve Djevojke (İyi Ölü Kızlar, 2002) toplumsal cinsiyet konusunu modernleşme sürecinin henüz başlangıcında savaş sonrası toplumu oluşturan farklı kimlik temsillerinin bulunduğu bir apartmanın içine yerleştirdiği lezbiyen bir çiftin öyküsü üzerinden gündeme getirmiştir. Matanić'in bu daha erken dönem filmi kadın öznelliğini tartışmaya açması açısından (dönemi içinde) oldukça cesur bir girişimdir. Öyle ki filmin çekilebilmesi için Matanić Tuđman'ın ölümünü ve milliyetçi HDZ partisinin iktidardan düşmesini beklemek durumunda kalmıştır. Mima Simić'e göre, politik sahnedeki bu ani değişim sonrasında dönemin auteur'leri otosansür zincirini kırmaya ve politik bakış açılarında olduğu kadar biçimsel olarak da daha karmaşık filmler üretmeye başlarlar (Simić, 2011, s.5). Matanić'in lezbiyen çifti yerleştirdiği çatışma evreni de savaş ve savaş sonrası döneminin ulus devletleşme politikalarının işlevleri olarak okunabilecek stereotipleridir. Iva ve Marija'nın kiracı olarak taşındığı bu apartman yeni Hırvat toplumunun bir metaforu, Simić'in deyişiyle grotesk bir aynasıdır (Simić, 2011, s. 5). Apartmanda başka bir dairede yaşayan ev sahiplerinin tekinsizliğine karşın lezbiyen çift, Matanić tarafından, bu küçük topluluğun en normal bireyleri olarak tanımlanmıştır. Çiftin komşuları şiddet yanlısı milliyetçi adam, ev sahibesi yaşlı, kuşkucu ve deli bir kadın, bir fahişe, zekâ geriliği olan bir başka genç adam, dairesinde yasadışı kürtajlar gerçekleştiren bir doktor, ev sahibesinin işsiz güçsüz oğlu gibi tiplerden oluşur. Apartmanın her dairesi, iki kadının varlıkları için tehdit içeren hücrelerdir.

Başlangıçta mutlu bir çift olarak yeni bir daireye taşınan Iva ve Marija'nın bedenleri, apartmanda yaşayanlar tarafından lezbiyen oldukları anlaşıldıktan sonra kolaylıkla hedef haline gelir. Taşındıkları daire ise onlara ait mahrem bir alan olmaktan çıkar, dışarıdan müdahaleye açık hale gelir. Iva ev sahibesinin oğlunun tecavüzüne uğrar, sevgilisi Marija ise kendisini ve Iva'yı savunurken öldürülecektir. Hayatta kalmayı başaran Iva'yı yıllar sonra evlenmiş ve normal bir aile kurmuş olarak görürüz. Kadın / lezbiyen özne, aile çatısının altına saklanmış, neredeyse gerçek kimliğini tamamen gizleyerek hayatta kalmıştır. Filmin adını yeniden anımsayan Simić, aslında olmadığı bir kimliği yaşamayı seçerek Iva'nın da öldüğünü vurgular (Simić, 2011, s. 6). Üstelik bedeniyle yeni ulus-devletin yeniden üretimine katılmıştır. 
Aslında Hırvat sinemasında kadın öznenin öykünün merkezinde konumlandığı az sayıdaki bu gibi örneklerde ilgi çekici olan yuvasından çıkan ve bireyleşme adına maceraya atılan ve atılmak zorunda kalan kadınların eve geri dönüşlerindeki ortaklıktır. Erkek özneler savaş sonrası travmanın gerçekleşemeyen özneleri olarak kurulsa da, erkeklik dışarda kendi ötekileri için çarpılacak veya eninde sonunda yıkılması istenecek bir duvar işlevi görmeye devam eder.

\section{Kapitalizm, Geç-Modernite ve Yozlaşma}

Yugoslavya'dan bağımsızlaşmanın biri ulus devletleşme olan iki ayağından diğeri kapitalist sisteme geçişin karanlık tarafıyla yüzleşmeye yönelen az sayıdaki filmden biri olan Ljudožder Vegetarijanac (Vejetaryen Yamyamlar, Branko Schmidt, 2012) bu yüzleşmeyi modern Hırvat toplumundaki yozlaşmayı bir doktorun, Danko'nun mafya ve polisle olan rüşvet ilişkisi üzerinden anlatır. Danko'nun uzmanlık alanının jinekoloji olması rastlantı değildir. Bir doktor olarak beden üzerinde doğrudan iktidar sahibi olan Danko'nun çalışma sahası özellikle kadın bedeni, dolayısıyla bu bedenden üreyecek bebek bedenleridir. Danko'yu sıradan bir doktor olmaktan alıkoyan yaptığı yasadışı kürtajlardır. Özgüveni yüksek, sağlıklı ve enerjik Danko'nun doktorluğu onun yeni sistem içindeki yerini sağlamlaştırır. Mafya tarafından kullanılan kadın bedenleri hamile kaldıklarında Danko'nun önüne gelirler. Danko sahip olduğu ilişkiler sayesinde arkasında bıraktığı kirli delilleri de temizleyerek sistemin en tepesine doğru ilerler. Böylece sonunda çalıştığı hastanenin başhekimliğine dek yükselecektir. Aslında bir aileye sahip olmak istemez. İnsanları, kadınları, ceninleri, ilişkileri, uyuşturucuları ve pahalı nesneleri sürekli tüketerek doyum arar. Steril, modern erkek bir birey olarak aslında Orman Yaratıkları'nda ormanda işçilerini avlayan şirket patronundan farksızdır. Danko bu yönüyle, savaş sonrası travması içinde yeni herhangi bir öznellik halini reddeden pek çok erkek karakterden oldukça farklıdır; yeni sistemle bir sorunu olmadığı gibi toplumsal geçmişe de sırtı dönüktür. Şimdiki zamanı tüketen, sürekli ilerleyen ve sadece kendine çalışan bir makine haline gelmiştir. Danko macera yolu eve dönüşle sonuçlanan kadın öznelerin çatıştığı tüm o engellerden bağımsız olduğu kadar onlar üzerindeki iktidarını sürekli hissedilir kılar. "Geç modernitenin başarıya ve performansa endeksli öznesi (subject) ise hiç kimsenin kulu değildir artık. Aslında herhangi bir zora da tabi değildir (subject to, sujét à). Kendini olumlular, hatta özgürleşerek bir proje haline getirir. Subject'ten / özneden projeye dö- 
nüşüm yine de şiddeti ortadan kaldırmaz " (Han, 2016, s. 20). Byung-Chul Han'ın da belirttiği gibi, geç-modernitenin başarı ve performans toplumu bir kendini-sömürme toplumudur. Birey iktidar adına kendini sömürür. Şiddet savaş sonrası geçilen yeni ekonomik ve toplumsal sistemde dışardan gelmez; içselleştirilmiş haliyle özneyi tamamen tükenene kadar böylece içeriden çürütür (Han, 2016, s. 19-20).

Tarihsel olarak on beş yıl gibi çok kısa bir dönemde ardında bıraktığı etnik savaştan ulus devletleşmeye ve hızlı bir Avrupalılaşma dönemine sahne olan Hırvatistan'ın sinema perdesine yansıyan görüntüsü Batı merkezli bir bakışın inşası olarak Balkan temsilinin yapısını bozarken, yerine önerdiği yeni öznellik biçimleri geçmişle gelecek arasında salınırlar. Yeni bir Balkan öznelliği inşa olacaksa bunun ulusal kimlikten bağımsız, hatta onunla çelişkili bir yapıda olması zordur. Dolayısıyla bu dönemde çekilmiş olan sinema filmlerinin geçmişin hangi karanlık odasını aydınlatırken, neden bir başkasını bilinçdışının karanlığında bırakmayı seçtiği de önem kazanır. Yeni sistemin içinde eylem sahibi olmayı reddeden ve kendini yok etmeyi seçen/düşleyen uyumsuz öznelerin sorunu henüz etkisini yitirmemiş yakın tarihledir. Onlar bir kurtuluş ve yeniden doğuş olarak kurulan yeni ekonomik ve politik sisteme dâhil olamayacak kadar travmatize olmuşlardır. Kapitalizmin yüzeydeki eleştirisi, birlikte yaşama / bir arada kalabilmenin grup içi dinamiklerinin yanında bir tema olarak belirse de yeni ekonomik sistem bu coğrafyada sınıf çatışması temelinde eleştirilmek için erken bir dönemini yaşamaktadır.

Uyumsuzların birlikteliğinin var olma koşullarının araştırıldığı, toplumsal fay hatlarının üzerinden geçildiği bu insan grupları amaçları bir tiyatro oyunu çıkarmak, ormanda hayatta kalmak veya sınır karakolunu korumak da olsa, kendilerini ötekileri olmaksızın kuramazlar. Bu yan yana gelme durumu yatay değil düşey dizgede kendi alt ve üst ötekilerini tanımlayarak, kendi öznelliğini bu ikisi arasında bir yerde konumlandırarak gerçekleşir. Yeni ulusal Balkan öznesi bu yüzden bir göçmen, Çingene veya Bosnalı ile bir Alman temsili arasında köprü işlevini öznellik düzeyine de taşımış olur. Balkan temsillerine özgü eski seyahat anlatı kalıbının yönü coğrafi düzeyde göçmen yolu olarak doğudan batıya yönelirken, kimliklerarası geçişe de yansır böylece. Geçmiş-gelecek; gelenek-modern; taşra-kent eksenleri öz-Balkanlaştırmanın eleştirisi, bireyleşme mücadelesi ve özellikle kadın öznenin özgürlük ve özerklik istemi için birbirinin yerini alan katmanlar ola- 
rak belirir. Toplumsal travmanın iyileşme süreci hala sürmekteyken, Hırvat sineması savaş suçlarının ve etnik-dinsel/mehzepsel ayrımlanmanın yanında, ataerkil toplumun baskısını, yeni sistemin yozlaşmaya dönmüş yüzünü de gündeme taşımıştır. Bununla birlikte, söz konusu dönemde, daha uzak geçmişle olan ilişkiler mesafelidir ve bu mesafe Nazi yanlısı Ustaša rejiminin veya sosyalist Tito iktidarının travmatik dönemlerini hatırlamaya yönelmez. ${ }^{8}$ Sinema toplumsal travmayla yüzleşmenin bir aracı ve politik bilinçaltının dışavurumu olarak düşünüldüğünde, yakın geçmişin yaralarının tazeliğini korumasına ek olarak, daha uzak geçmişe dair travmalar, onlara sebep olan somut tarihsel çatışmaların çağdaş sinemanın yüzeye çıkarması ile iyileşme yoluna girebilecektir.

\section{Kaynakça}

Angelopoulos, T. (Yönetmen) (1995). To vlemma tou OdYssea [Film]. Yunanistan, Fransa, İtalya, Almanya, Birleşik Krallık, Federal Yugoslavya Cumhuriyeti, Bosna Hersek, Arnavutluk, Romanya: Paradis Films, Basic Cinematografica, Istituto Luce, Th. Angelopoulos Productions, vd.

Brešan, V. (Yönetmen). (2008). Nije Kraj [Film]. Hırvatistan, Sırbistan: HRT, Interfilm, Vans.

Demir, H. (2017). Birinci ve İkinci Yugoslavpa'da Hurvat Sorunu. (Yayınlanmamış doktora tezi) Sakarya Üniversitesi, Sosyal Bilimler Enstitüsü, Sakarya.

Grlić, R. (Yönetmen). (2006). Karaula [Film]. Hırvatistan, Slovenya, Sirbistan, Bosna-Hersek vd.: Refresh Production vd.

Han, B.C. (2016). Şiddetin Topolojisi (Çev. D. Zaptçıŏlu). İstanbul: Metis.

Iordanova, D. (2007). Balkan Sineması, Alevler İçinde Sinema (Çev. B. Erdoğan). İstanbul: Agora.

8 Bir dönem filmi olarak Lea \& Darija (Branko Ivanda, 2011) Hırvat Ustaša Partisi'nin Nazilere ve Yahudi soykırımına verdiği desteğin sonuçlarını biri Yahudi diğeri Katolik iki kız çocuğunun hikâyesi üzerinden aktarsa da çağdaş sinema uzak geçmişe ait başka travmatik dönemlere çok fazla eğilmemiş görünmektedir. Öyle ki, ötekileştirmenin farklı biçimleri geçmişte Hırvatistan sahnesinde de sürmüş olan Yahudi soykırımında olduğu gibi, sosyalist rejimin iktidara geldiğinde Ustaša üyelerini aileleriyle birlikte katlettiği tarihsel olaylarda da varlığını sürdürmektedir Detaylı bir okuma için bkz. Demir (2017, s. 63-102). 
Jameson, F. (2011). Siyasal Bilinçdışı (Çev. Y.Alogan, M. Varlık). İstanbul: Ayrintı.

Jelčić, B. (Yönetmen). (2013) Obrana i Zaštita [Film]. Hırvatistan: Zdenka Gold / Spiritus movens.

Jurić, Z.; Dević, G. (Yönetmen). (2009). Crnci [Film]. Kinorama, HTV.

Kakogiannis, M. (1964). Alexis Zorbas [Film]. Yunanistan, ABD: 20th Century Fox.

Kiseljak, M. (2012). Recite Aljazeeri: Slavoj Žižek [TV Program]. Slavoj Žižek'le söyleşi, Al Jazeera Balkans. https://www.youtube.com/wat$\mathrm{ch} ? \mathrm{v}=\mathrm{cDaE8LkO6AU}$

Kovačević, N. (2013). Re-Worlding The Balkans: Films of Voyage to the European Union. European Journal of English Studies, 17:2, 188200.

Kusturica, E. (1995). Underground [Film]. Yugoslavya Federal Cumhuriyeti, Fransa, Almanya, Bulgaristan, Çekya, Macaristan: CiBy 2000, Pandora Filmproduktion, Novofilm, Barrandov Studios, vd.

Manchevski, M. (Yönetmen). (1994). Before The Rain [Film]. Makedonya, İngiltere, Fransa: Aim, British Screen Productions, European Co-production Fund, vd.

Matanić, D. (Yönetmen). (2002). Fine Mrtve Djevojke [Film]. Hırvatistan: Alka-Film Zagreb.

Matanić, D. (Yönetmen). (2010). Majka Asfalta [Film]. Hırvatistan: HRT, Kinorama.

Mršić, T. (Yönetmen). (2013). Kauboji [Film]. Hirvatistan: Kabinet.

Pavičić, J. (2011). From a Cinema of Hatred to a Cinema of Consciousness: Croatian Film after Yugoslavia. Kinokultura, Special Issue 11. http://www.kinokultura.com/specials/11/pavicic.shtml

Said, E.W. (2014). Şarkiyatçılık: Batı'nın Şark Anlayışları (Çev. B. Ülner). İstanbul: Metis.

Schmidt, B. (Yönetmen). (2006). Put Lubenica [Film]. Hirvatistan: HRT

Schmidt, B. (Yönetmen). (2012). Ljudožder Vegetarijanac [Film]. Hırvatistan: Telefilm, Croatian Radiotelevision. 
Simić, M. (2011). Gender in Contemporary Croatian Film, Kinokultu$\mathrm{ra}$, Special Issue 11. http://www.kinokultura.com/specials/11/simic. shtml

Sönmez, S. (2014). Filmlerle Hatırlamak Toplumsal Travmalarn Sinemada Temsil Edilişi. İstanbul: Metis.

Sviličić, O. (Yönetmen). (2007). Armin [Film]. Hırvatistan, Bosna-Hersek: HRT, Refresh Production vd.

Šerbedžija, D. (Yönetmen). (2010). Sedamdeset i Dva Dana [Film]. Hırvatistan, Sirbistan: HRT, Interfilm, Lijeni Film, Vans.

Tardozzija, A. (Yönetmen). (2011). Fleke [Film]. Hırvatistan: Kinoteka. Todorova, M. (1997). Imagining the Balkans. New York: Oxford University Press.

Vitez, I.-G. (Yönetmen). (2010). Šuma Summarum [Film]. Hirvatistan: Propeler Film, Kinorama.

Vojković, S. (2008). De/re-construction of subjectivity in contemporary Croatian cinema: becoming European. New Review of Film and Television Studies. 6:1, 83-95.

Žižek, S. (2001). The Fragile Absolute: Or, why is the Christian Legacy Worth Fighting For? London \& New York: Verso. 